\title{
A Better Way: Rethinking SB 123 Probationary Drug Treatment in Kansas*
}

\section{INTRODUCTION}

There is no denying that drug abuse and addiction have plagued our nation's criminal justice system. ${ }^{1}$ Drugs have not only destroyed the lives of millions of Americans, but have also propagated a host of offenses across the criminal spectrum. ${ }^{2}$ Today, an enormous share of inmates across the country report histories of drug use. ${ }^{3}$ Kansas inmates are no exception. ${ }^{4}$ The Kansas Sentencing Commission reported that Kansans committed more drug crimes ${ }^{5}$ in 2012 than any other offense. ${ }^{6}$

* R. Patrick Springer. J.D. Candidate 2015, University of Kansas School of Law; B.S. (Criminology) 2012, Missouri State University; A.S.N. (Registered Nurse) 2009, Mercy College of Nursing at Southwest Baptist University. I would first like to thank my Note and Comment Editor, Peter Montecuollo, for going above and beyond the call of duty. His help was truly invaluable in drafting this comment. I would also like to thank the Kansas Law Review staff and board for all of their hard work. Finally, I would like to thank my wife, Brittany, for her ceaseless love and support.

1. Nat'l Ctr. on Addiction \& Substance Abuse, Behind Bars II: Substance Abuse AND AMERICA'S PRISON POPULATION 1 (2010), available at http://www.casacolumbia.org/download/file/fid/487 (providing the startling fact that in 2005 "federal, state, and local governments spent $\$ 74$ billion in court, probation, parole and incarceration costs of adult and juvenile substance-involved offenders").

2. See Christopher J. Mumola \& Jennifer C. Karberg, Drug Use and Dependence, STATE AND FEDERAL PRISONERS, 2004, at 5-6 (2006), available at http://www.bjs.gov/content/pub/pdf/dudsfp04.pdf (explaining that one-fourth of violent offenders in prison committed the offense while under the influence of drugs, and one-third of property offenders in state prison were motivated by the need for drug money); see also EXECUTIVE OFFICE OF THE President, OfFice of NAT'L Drug Control Policy, How Illicit Drug Use AfFects Business AND THE ECONOMY (2011), available at http://www.whitehouse.gov/sites/default/files/ondcp/Fact_Sheets/effects_of_drugs_on_economy_jw _5-24-11_0.pdf (drug abuse cost our nation's criminal justice system $\$ 61$ billon dollars in 2007 (last available estimate)).

3. See MuMOLA \& KARBERG, supra note 2, at 1-2 (approximately $69 \%$ of state prisoners, and approximately $64 \%$ of federal prisoners, reported regular drug use; $32 \%$ of state prisoners, and $26 \%$ of federal prisoners reported using drugs at the time of the offense).

4. Kansas Department of Corrections secretary, Ray Roberts, noted this past summer that the Kansas prison system is at full capacity, and "[s]ubstance abuse and mental illness - those are the two big drivers." Hurst Laviana, Corrections Secretary: Kansas Prisons are Running at Capacity, WichiTA EAGLE (July 19, 2013), http://www.kansas.com/2013/07/19/2896260/correctionssecretary-prisons.html.

5. "Drug crime" refers to those crimes involving controlled substances, for example, "unlawful possession of a controlled substance," "unlawful manufacturing of a controlled 
Of the over 13,000 offenders sentenced across the state in 2012, roughly $30 \%$ of those offenders were sentenced for drug offenses. ${ }^{7}$ Indeed, the gravity of this problem is so understood that further acknowledgement seems to only harden our collective sentiment that the problem is incurable.

Thus, courts across the country have struggled to determine how best to deal with this problematic and ever-increasing population of offenders. While incarceration has been the traditional curative nationwide, prison sentences have not had the intended deterrent effect on drug offenders ${ }^{8}$ and drug-involved offenders. ${ }^{9}$ In fact, offenders struggling with drug addiction have such an extreme rate of recidivism that the problem has been likened to a "revolving door." 10 Many jurisdictions have come to realize that simply locking up drug-involved offenders is ineffective. ${ }^{11}$

substance," "unlawful cultivation or distribution of a controlled substance," etc. See Kan. STAT. ANN. §§ 21-5701 to -5717 (West 2013).

6. KAN. SENTENCING COMM'N, FY 2012 ANNUAL REPORT 5 (2013), available at http://www.sentencing.ks.gov/document-center/reports.

7. Id.

8. For the purposes of this Comment, the term "drug offender" refers to the offender convicted of a drug crime, for example illegal possession, manufacturing, distribution, etc. The term "drug-involved offender" (or "substance-involved offender") is broader and refers to any criminal offender who abuses drugs.

9. See James P. Gray, Why Our Drug Laws Have Failed and What We Can Do About IT: A JUDICIAL INDICTMENT OF THE WAR ON DRUGS 30-31 (2d ed. 2012) (noting that former Drug Czar in the Clinton Administration, Barry McCaffrey, has even acknowledge that "we have a failed social policy and it has to be re-evaluated. Otherwise, we're going to bankrupt ourselves. Because we can't incarcerate our way out of this problem.").

10. State v. Preston, 195 P.3d 240, 244 (Kan. 2008) (referring to a February 12, 2003 memorandum from Kansas Sentencing Commission to the Senate Judiciary Committee); see also NAT'L CTR. ON ADDICTION \& SUBSTANCE ABUSE, supra note 1, at 5 ("Substance-involved offenders are likelier to recidivate than those who are not substance involved. Over half (52.2 percent) of substance-involved inmates have one or more previous incarcerations compared with 31.2 percent of inmates who are not substance involved.").

11. It is now widely acknowledged that a war-on-drugs mentality, steeped in deterrence, is an ineffective approach to the problem. Over the last forty years, despite the continued imposition of stiff penalties, the use of illegal drugs has continued across the country. See generally GraY, supra note 9, at 17-158 (describing the history of drug laws in the United States and how modern drug laws have harmed communities and drug users themselves).

This is the reality we are facing. Under our current policy, drugs are everywhere ....

Our current system is completely unable to keep illicit drugs out of our communities and away from our children. Even Joseph A. Califano, the former Secretary of the U.S. Department of Health, Education and Welfare and the chairman of the Columbia University Center on Addiction and Substance Abuse said, 'American children are telling us they are drenched in drugs.'

Id. at 50-51. See also NAT'L CTR. ON AdDiction \& SubStAnce Abuse, supra note 1, at 5 ("Breaking the cycle of re-arrest and re-incarceration requires breaking the cycle of addiction.”). 
The reason for this is simple. Drug addiction, by its very nature, cannot be cured through incarceration. ${ }^{12}$

To address this revolving-door problem, many states have turned to drug courts. By combining probation, drug treatment, and continuous judicial supervision, drug courts have proven themselves an enormous success. ${ }^{13}$ Indeed, "[m]ore research has been published on drug courts ... than virtually all other correctional programs combined."14 Not only have drug courts saved countless dollars, but, more importantly, they have proven themselves extremely effective in breaking the cycle of addiction and recidivism. ${ }^{15}$ In response to such favorable results, many states have established drug courts as a long-term solution to crime emanating from drug abuse and addiction. ${ }^{16}$

In 2010, the Kansas Supreme Court contacted the National Center for State Courts (NCSC) to "research the feasibility and practicality of instituting state-wide level management over drug courts within the state." The question was whether Kansas should "support and institutionalize, at the state level, the development of traditional drug courts."18 The report provided by the NCSC describes

12. See Hon. Peggy F. Hora \& Theodore Stalcup, Drug Treatment Court in the Twenty-First Century: The Evolution of the Revolution in Problem-Solving Courts, 42 GA. L. REv. 717, 721 (2008) ("Incarceration does little to change substance use patterns. Subsequent to release, exoffenders continue to use alcohol or other drugs at alarming rates.").

13. Nat'l Drug Court Inst., The Drug Court Judicial Benchbook 1 (Douglas B. Marlowe \& William J. Meyer eds., 2011) [hereinafter JudiCIAL BENCHBOOK] ("Five independent meta-analyses - advanced statistical procedures conducted by rigorous scientific teams-have concluded that drug courts reduce crime and substance abuse. The most conservative estimates indicate that drug courts save money for taxpayers on the order of two to four times the initial investment. In short, drug courts work!"); see also Hon. Jerome Eckrich \& Roland Loudenburg, Answering the Call: Drug Courts in South Dakota, 57 S.D. L. REV. 171, 179 (2012) (noting that "[a]lthough there are criticisms with regard to the research published about the effectiveness of drug courts, the value of drug courts and their positive effect on recidivism cannot be denied," and "[t]he research now available... has reliably demonstrated that drug courts outperform virtually all other strategies that have been used with drug-involved criminal offenders").

14. JUDICIAL BENCHBOOK, supra note 13, at 1 .

15. Id.; see also Douglas B. Marlowe, NAT'L Assoc. OF Drug Court Prof'Ls, Research UPDATE ON ADULT DRUG COURTS 1-3 (2010), available at http://www.nadcp.org/sites/default/files/nadcp/Research\%20Update\%20on\%20Adult\%20Drug\%20 Courts\%20-\%20NADCP_1.pdf (providing various studies on the effectiveness of drug courts, not only by reducing recidivism, but also by "elicit[ing] substantial improvements in other outcomes apart from criminal recidivism").

16. See infra notes 78-99 and accompanying text.

17. Nat'l Ctr. For State Courts, Kansas Drug Court Feasibility Study 1 (2011), available at http://www.sji.gov/PDF/KS_Drug_Court_Feasibility_Study.pdf [hereinafter FEASIBILITY STUDY].

18. Id. 
"institutionalization" as "the process by which individual drug courts evolve from separate experimental entities to a statewide network that is stable, far-reaching, reliably funded and closely monitored." ${ }^{\prime 19}$ Though a handful of Kansas counties are currently operating drug courts, ${ }^{20}$ Kansas has yet to institutionalize drug courts at the state level. ${ }^{21}$ The Kansas Legislature, however, has not ignored this revolving-door problem posed by drug-involved offenders. As the NCSC study notes, in 2003 the state legislature passed Senate Bill 123 (SB 123). ${ }^{22}$ This law institutionalized mandatory drug treatment under probationary supervision for certain drug-involved offenders. ${ }^{23}$

SB 123 is the central focus of this Comment. Specifically, this Comment examines certain provisions of SB 123 and how these provisions relate to drug court practice. When scrutinized, SB 123 has several deficiencies. First, the eligibility and admission requirements of SB 123, which limit the program to a specific class of offenders, undermine the law's effectiveness and hinder its goals. Second, SB 123 lacks the cornerstone of essential drug court practice: continuous judicial supervision. Third, the compulsory nature of SB 123, the law's ability to impose broad and far-reaching sanctions, and its denial of jail-time credit in light of its own strict termination requirements, are not only counterproductive, but also raise constitutional concerns regarding due process. Because of these concerns and deficiencies, SB 123 should be replaced through the state-wide institutionalization of drug courts; and, even if not replaced, SB 123 should not serve as a model if drug courts are institutionalized in Kansas.

\section{BACKGROUND}

\section{A. An Overview: SB 123 Drug Treatment}

In 2003, the Kansas Legislature enacted SB 123, thus creating an alternative sentencing policy for first-time, non-violent drug offenders. ${ }^{24}$

\footnotetext{
19. Id. at 2.

20. See U.S. Drug Court Map: Find a Drug Court in Your Community, NAT'L Ass'N OF Drug COURT PROF'LS, http://www.nadcp.org/learn/find-drug-court (last visited Apr. 2014) (interactive map showing that there are currently eight adult drug courts in Kansas, specifically in Allen, Cowley, Geary, Lynon, Sedgwick, Shawnee, and Wyandotte counties).

21. FeASIBILITY StUdy, supra note 17, at 1 .

22. Id. at 4 .

23. Id. at 5. Today, SB 123 is codified in section 21-6824 of Kansas Statutes Annotated.

24. 2003 Kan. Sess. Laws Ch. 135 (S.B. 123).
} 
The Kansas Supreme Court reiterated the goal of SB 123:

[T]he Kansas Sentencing Commission identified the goal of the alternative drug policy (S.B. 123) as: 'to provide community punishment and the opportunity for treatment to nonviolent offenders with drug abuse problems in order to more effectively address the revolving door of drug addicts through the state prisons, which should be reserved for serious, violent offenders. ${ }^{25}$

The law provides probationary supervision and mandatory drug treatment for a select class of drug-involved offenders. ${ }^{26}$ Over the past ten years, SB 123 has remained essentially the same, and today is codified in section 21-6824 of the Kansas Statutes Annotated. ${ }^{27}$ The eligibility and admission requirements of SB 123 are discussed below, as well as the law's provisions regarding treatment and termination.

\section{Eligibility}

SB 123 drug treatment is limited to a certain class of offenders. First, it is limited to only adult offenders convicted of unlawfully possessing a controlled substance under section 21-6706. ${ }^{28}$ Offenders convicted of unlawfully manufacturing controlled substances (K.S.A. $\S$ 21-5703), unlawfully cultivating or distributing a controlled substance (K.S.A. § 21-5705), or unlawfully deriving proceeds from the sale, manufacture, or distribution of drugs (K.S.A. § 21-5716) are not eligible for SB 123 drug treatment. ${ }^{29}$

Second, SB 123 is limited to only first-time and second-time felony possession offenders. According to the Kansas sentencing grid for drug crimes, "The sentence for a third or subsequent felony conviction of . . . [unlawful possession of a controlled substance] . . . shall be a presumptive term of imprisonment and the defendant shall be sentenced

\footnotetext{
25. State v. Preston, 195 P.3d 240, 244 (Kan. 2008) (quoting a 2003 memorandum from Kansas Sentencing Commission to the Senate Judiciary Committee).

26. Kan. Sentencing Comm'N \& Kan. Dept. Corr., 2003 - Senate Bill 123 "Alternative Sentencing Policy for Non-Violent Drug Possession OfFenders" OPERATIONS MANUAL ch. 4-1, 4-2 (2008), available at http://sentencing.ks.gov/docs/defaultsource/sb-123/sb-123-operations-manual.pdf?sfvrsn=0 [hereinafter $\quad$ SB 123 OPERATIONS MANUAL] (an updated version of the SB 123 Operations Manual is currently undergoing construction according to the Kansas Sentencing Commission's website).

27. KAN. STAT. ANN. § 21-6824 (West 2013) (formerly K.S.A. § 21-4729).

28. Id. §21-6824(a).

29. Id. § 21-6824(a)(1)-(2).
} 
to prison as provided by this section. $" 30$ This term of imprisonment will not be subject to modification if the offender: (1) previously completed drug treatment or intensive substance abuse treatment; (2) was previously discharged from drug treatment or intensive substance abuse treatment; or (3) previously refused to participate in drug treatment or intensive substance abuse treatment. ${ }^{31}$ In short, the offender gets one shot at treatment.

\section{Admission Process}

Offenders who meet the eligibility criteria above will be subject to a drug abuse assessment which "shall include a clinical interview with a mental health professional and a recommendation concerning drug abuse treatment for the offender." 32 These offenders will also be subject to a criminal risk-need assessment, which "shall be conducted by a court services officer or a community corrections officer." 33 If the offender is assigned a high-risk status according to the drug abuse assessment, and a moderate-risk or high-risk status according to the criminal risk-need assessment, then the sentencing court shall commit the offender to an SB 123 drug abuse treatment program. ${ }^{34}$ In other words, for eligible offenders who meet the assessment qualifications, SB 123 drug treatment is mandatory. Whether the offender actually desires treatment, or instead wishes to serve the underlying sentence, is irrelevant. The sentencing court is required to sentence the offender to SB 123 drug treatment.

\section{Treatment and Supervision}

The drug treatment providers must be licensed by the state to provide such treatment, as well as certified by the secretary of corrections to participate in the SB 123 program. ${ }^{35}$ While in drug treatment, the offenders will be supervised by the Kansas Community Correctional Services. ${ }^{36}$ In addition to traditional duties, when working with an

\footnotetext{
30. Id. § 21-6805(f)(1) (emphasis added).

31. Id. $\S 21-6805(\mathrm{f})(1)-(2)$ (intensive substance abuse treatment is conducted during an offender's term of imprisonment at a designated facility).

32. Id. $\S 21-6824(\mathrm{~b})(1)$.

33. Id. § 75-52,144(b).

34. Id. §21-6824(c).

35. SB 123 OPERATIONS MANUAL, supra note 26, at ch. 4-5, 4-6, 5-11 (community correction agencies will also provide authorization for the drug treatment services provided to the offender).

36. KAN. StAT. ANN. § 21-6824(d)(1) (West 2013).
} 
offender sentenced under SB 123, the community correctional officer also "work[s] with the substance abuse treatment staff to ensure effective supervision and monitoring of the offender." 37 The probation officer and treatment providers are required to regularly conduct team meetings to discuss the progress of the offender and whether greater supervision is needed. ${ }^{38}$

Treatment lasts for a period not to exceed eighteen months. ${ }^{39}$ During treatment, SB 123 attempts to address the continuous needs of each particular offender in two ways. First, courts have the ability to modify the level of treatment in order to meet an offender's needs as they evolve. $^{40}$ As the Kansas Supreme Court noted in State v. Preston, the legislature intended the SB 123 program to "match the level of [drug] treatment to the offender's particular substance abuse needs." 41 Such modification, furthermore, is not limited to an initial needs assessment. "[T] effect the goals of the legislation," as the court noted in Preston, "the S.B. 123 substance abuse treatment program must be amenable to modification or revision to meet the offender's current needs, as those needs change or become more clearly defined." 42 The court noted that the particular defendant at issue, after being sentenced to SB 123 drug treatment, had subsequently demonstrated that she was "unable to handle her addiction problem while on her own." court was justified in modifying her SB 123 treatment program by ordering her to attend inpatient treatment. ${ }^{44}$

Second, courts have the ability to address current offender needs via sanctions if the offender subsequently violates a condition of his or her treatment program. "Such non-prison sanctions shall include, but not be limited to, up to 60 days in a county jail, fines, community service, intensified treatment, house arrest and electronic monitoring." 46 For example, an offender may be required to perform community service for failing to participate in treatment, spend a short amount of "shock time" in jail for failing to undergo a drug test, or be required to undergo

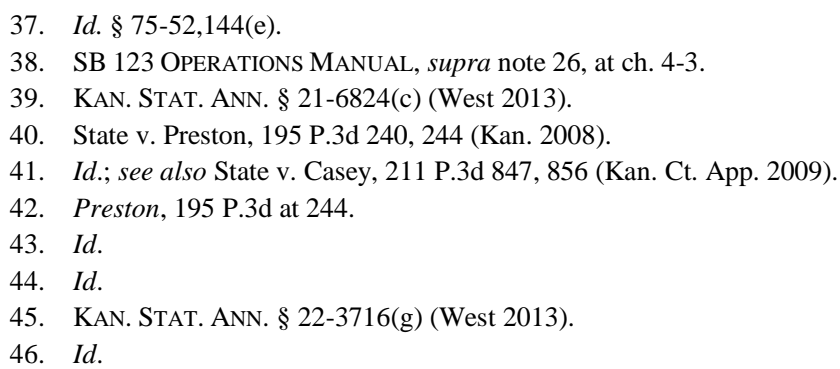


inpatient drug treatment for failing a drug test. Essentially, these sanctions act as the proverbial "stick" to coerce the offender into complying with drug treatment. ${ }^{47}$

\section{Termination}

Offenders in SB 123 drug treatment programs shall be terminated from treatment if they (1) are "convicted of a new felony," or (2) establish a "pattern of intentional conduct that demonstrates [their] refusal to comply with or participate in the treatment program as established by judicial finding." ${ }^{48}$ To be clear, as the language of K.S.A. section 21-6824 explicitly states, termination is mandatory in either of these two circumstances. Moreover, judges may abuse their discretion if they do not terminate an offender from SB 123 treatment following one of these occurrences. ${ }^{49}$ The Kansas Supreme Court has held that once a court has found that an offender has committed a new felony or engaged in a pattern of intentional conduct demonstrating refusal to comply, the court is required to revoke SB 123 drug treatment and impose the underlying sentence. ${ }^{50}$

The courts, however, are not limited to only the above two circumstances as a basis for revoking treatment. The Kansas Supreme Court held in State v. Gumfory:

[N]othing in the language of [K.S.A. § 21-6824(f)(1)(A)-(B)] suggests that these are the only occasions when an offender may be discharged. ... As such, we conclude that [K.S.A. § 21-6824(f)(1)(A)(B) does] not set forth the exclusive grounds for revocation of S.B. 123 probation; rather, they set forth the grounds for when the district court must revoke the offender's S.B. 123 probation. ${ }^{51}$

The Gumfory court recognized that district courts have broad

47. See SB 123 Operations Manual, supra note 26, at ch. 4-2 (discussing the ability to sanction SB 123 probationers under the heading "Offender Accountability").

48. KAN. StAT. ANN. § 21-6824(f)(1) (West 2013).

49. See State v. Green, 153 P.3d 1216, 1225 (Kan. 2007) ("An abuse of discretion may be found if a district judge's decision goes outside the framework of or fails to properly consider statutory limitations or legal standards." (emphasis added) (citations omitted)).

50. State v. Bee, 207 P.3d 244, 249 (Kan. 2009) (noting that the "statutory language 'shall' generally represents a mandatory course of conduct," and that because a judicial finding established that the defendant had not complied with treatment, the district court was required to revoke the treatment program (citations omitted)); see also State v. Craven, No. 102,557, 2010 WL 1078472, at *1-2 (Kan. Ct. App. Mar. 19, 2010).

51. State v. Gumfory, 135 P.3d 1191, 1196 (Kan. 2006). 
discretion to impose conditions on general probation. ${ }^{52}$ The court reasoned that it was unlikely that the legislature would grant a court such broad discretion to impose conditions, only to then limit its ability to revoke an offender's probation because he "violated some terms of his probation rather than others." ${ }^{33}$ Furthermore, the grant of such broad discretion, both in the imposition of conditions and ability to revoke, applies to SB 123 probation as well. ${ }^{54}$

It is important to note that upon revocation there is a significant difference between SB 123 probation and "standard" probation. Offenders placed on standard probation are statutorily granted a jail-time credit in the event their probation is revoked and they are sentenced to confinement. ${ }^{55}$ Standard probationers who spend time in a residential facility, conservation camp, or community correctional residential services program, have the length of their sentences reduced by the amount of time they spent in these facilities. ${ }^{56}$ Courts are required to provide this jail-time credit to standard probationers facing revocation. ${ }^{57}$ This is not the case for offenders sentenced to SB 123 probation. "The amount of time spent participating ... shall not be credited as service on the underlying prison sentence." 58 This legislative denial of a jail-time credit to SB 123 probationers (along with the mandatory nature of SB 123) has created two classes of probationers in Kansas. The Kansas Supreme Court has upheld this legislative distinction, ruling that it is not a violation of equal protection. ${ }^{59}$ As the court noted, offenders sentenced to SB 123 drug treatment comprise a separate class of probations and are therefore not treated equally by being denied "jail-time" credit when their SB 123 probation is revoked. ${ }^{60}$

\footnotetext{
52. $I d$.

53. Id.

54. Id.

55. KAN. STAT. ANN. § 21-6615(b) (West 2013).

56. Id.

57. See State v. Theis, 936 P.2d 710, 712 (Kan. 1997) (holding that, for standard probationers, “'[j]ail-time credit' must be determined by the sentencing court and included in the journal entry at the time the trial court sentences the defendant to confinement"); see also State v. King, 793 P.2d 1267, 1269 (Kan. Ct. App. 1990) ("[Credit] for time served [is] ... mandatory rather than discretionary and discloses legislative intent to give criminal defendants placed on probation credit for all time spent in custody during probationary periods.").

58. KAN. Stat. ANN. § 21-6604(n)(1) (West 2013) (emphasis added).

59. State v. Preston, 195 P.3d 240, 245 (Kan. 2008); see also infra Part III.C.3.

60. Id.
} 


\section{B. An Overview: Drug Courts}

\section{Defining Drug Courts}

Having examined SB 123 probationary drug treatment in Kansas, it is important to compare the program to drug courts. A "drug court" is a specialized court within a local court system that is designed to treat individuals addicted to drugs. ${ }^{61}$ "The mission of drug courts," as established by the Bureau of Justice Assistance, "is to stop the abuse of alcohol and other drugs and other related criminal activity." ${ }^{\text {, }}$ A drug court essentially uses "the criminal system to treat drug addiction through judicially monitored treatment rather than incarceration or probation." 63 This combination of probation, drug treatment, and continuous judicial supervision is the distinctive feature of drug courts. A drug court is composed of a team of professionals that includes: a judge, prosecutor, defense attorney, treatment providers, case managers, probation officers, and other law enforcement representatives. ${ }^{64}$ This team works with the participant throughout his or her time in drug court and each team member provides unique input regarding the participant's progress. ${ }^{65}$ Within this team, the judge is essential. The judge is not only the ultimate decision maker, but also an active participant who directs the process forward. ${ }^{66}$

An offender enters drug court through a variety of adjudicatory pathways, for example pre-plea, pre-adjudication, or post-adjudication plea agreement. ${ }^{67}$ An offender generally participates in drug court for a general period of twelve to eighteen months and is expected to adhere to an individualized treatment plan, undergo weekly drug tests, and attend regular status hearings in front of the entire drug court team. ${ }^{68}$ The judge may impose positive or negative consequences-rewards for good

61. West Huddleston \& Douglas B. Marlowe, Nat’L Drug Court Res. Ctr., Painting the CuRrent Picture: A National Report on Drug Courts and Other Problem-Solving COURT PRograms IN THE United StATES 7 (2011), available at http://www.ndcrc.org/sites/default/files/pcp_report_final_and_official_july_2011.pdf.

62. Bureau of Justice Assistance, Defining DRug Courts: The TEN Key Components 1 (2004), available at http://www.ndci.org/sites/default/files/nadcp/Key_Components.pdf [hereinafter TEN KEY COMPONENTS].

63. FEASIBILITY STUDY, supra note 17, at 41 .

64. HudDLESTON \& MARLOWE, supra note 61 , at 7.

65. Id.

66. See JudiCiAL BeNCHBOOK, supra note 13, at 48 .

67. Id. at 33-35.

68. HudDLESTON \& MARLOWE, supra note 61 , at 7. 
behavior or punitive sanctions for noncompliance (such as failing a drug test or missing a status hearing). ${ }^{69}$

\section{Target Population}

Drug courts generally target drug-dependent (addicted) ${ }^{70}$ persons who have committed non-violent offenses because of their addiction. ${ }^{71}$ It is important to note that eligibility is not limited only to individuals who have committed drug-related offenses. ${ }^{72}$ Drug courts also seek individuals charged with offenses "which are determined to have been caused or influenced by their addiction such as theft, burglary, or forgery." 73 Such an offender is considered both "high need" and "high risk." "High need" refers to those disorders or impairments that "if treated, substantially reduce the likelihood of continued engagement in crime." ${ }^{, 74}$ The most common need is usually substance dependence. ${ }^{75}$ "High risk," on the other hand, refers to the "likelihood that an offender

69. Id.

70. "The essential feature of [s]ubstance [d]ependence [i.e. drug addiction] is a cluster of cognitive, behavioral, and physiological symptoms indicating that the individual continues use of the substance despite significant substance-related problems.” AM. PSYCHIATRIC Ass'N, DiAGNOSTIC \& Statistical Manual of Mental Disorder, Fourth Edition 176 (4th ed. 1994). Diagnostic criteria for substance dependence:

A maladaptive pattern of substance use, leading to clinically significant impairment or distress, as manifested by three (or more) of the following [seven identifiers] occurring at any time in the same 12-month period: (1) tolerance, as defined by either . . . a need for markedly increased amounts of the substance to achieve intoxication . . . [or a] markedly diminished effect with continued use of the same amount of the substance; (2) withdrawal, as manifested by either ... the characteristic withdrawal syndrome for the substance... [or] the same (or closely related) substance is taken to relieve or avoid withdrawal symptoms; (3) the substance is often taken in larger amounts or over a longer period than was intended; (4) there is a persistent desire or unsuccessful efforts to cut down or control substance use; (5) a great deal of time is spent in activities necessary to obtain the substance... use the substance, or recover from its effects; (6) important social, occupational, or recreational activities are given up or reduced because of substance use; (7) the substance use is continued despite knowledge of having a persistent or recurrent physical or psychological problem that is likely to have been caused or exacerbated by the substance. ...

Id. at 181 .

71. HudDLESTON \& MARLOWE, supra note 61 , at 7.

72. What Are Drug Courts?, NAT'L ASS'N OF Drug COURT Prof'Ls, http://www.nadcp.org/learn/what-are-drug-courts (last visited Apr. 20, 2014).

73. HudDLESTON \& MARLOWE, supra note 61 , at 7.

74. Douglas B. Marlowe, Drug Court Practitioner Fact Sheet: Targeting the RIGHT PARTICIPANTS FOR ADULT DRUG COURTS 3 (2012), available at http://www.ndci.org/sites/default/files/nadcp/Targeting_Part_I.pdf.

75. $I d$. 
will not succeed on standard supervision and will continue to engage in the same pattern of behavior that got him or her into trouble in the first place." ${ }^{, 76}$ Research has shown that drug courts:

[T]end to have the most powerful effects for drug offenders who are both high risk and high need, meaning that they have serious substance abuse disorders and also have a history of a poor response to standard treatment and/or antisocial personality traits.... If a drug court focuses on low-severity offenders, it is less likely to achieve meaningful cost savings for its community that would justify the additional expense and effort of the program. ${ }^{97}$

\section{The Ten Key Components}

Established by the Bureau of Justice Assistance, in collaboration with the National Association of Drug Court Professionals (NADCP), drug courts adhere to the Ten Key Components of Drug Courts. ${ }^{78}$ They are as follows:

1. Drug courts integrate alcohol and other drug treatment services with justice system case processing.

2. Using a non-adversarial approach, prosecution and defense counsel promote public safety while protecting participants' due process rights.

3. Eligible participants are identified early and promptly placed in the drug court program.

4. Drug courts provide access to a continuum of alcohol, drug, and other related treatment and rehabilitation services.

5. Abstinence is monitored by frequent alcohol and other drug testing.

6. A coordinated strategy governs drug court responses to participants' compliance.

7. Ongoing judicial interaction with each drug court participant is essential.

8. Monitoring and evaluation measure the achievement of program goals and gauge effectiveness.

76. Id.

77. JUDICIAL BENCHBOOK, supra note 13, at 32 .

78. TEN Key COMPONENTS, supra note 62, at 1. 
9. Continuing interdisciplinary education promotes effective drug court planning, implementation, and operations.

10. Forging partnerships among drug courts, public agencies, and community-based organizations generates local support and enhances drug court program effectiveness.

The components listed above are no small thing. They are evidencebased best practices, with research confirming that "how well drug courts accomplish their goals depends upon how faithfully they adhere to the Ten Key Components." Ten Key Components suffer from lower graduation rates, higher recidivism rates, and do not generate substantial cost savings. ${ }^{81}$ Indeed, these components have since become the national standard for drug courts. ${ }^{82}$ Further, any county seeking to establish or maintain their own drug court must adhere to the Ten Key Components to receive federal funding. ${ }^{83}$ Today, there are drug courts in every state, and many states have statutorily institutionalized drug courts along the NADCP modelfully integrating them into their criminal justice systems. Again, "institutionalization" can be described as the process by which states create a statewide network of drug courts that are stable, closely monitored, and reliably funded. ${ }^{84}$

In Missouri, "[d]rug courts may be established by any circuit court ... to provide an alternative for the judicial system to dispose of cases which stem from drug use." 85 Moreover, drug courts in Missouri "shall combine judicial supervision, drug testing and treatment of drug

\footnotetext{
79. Id. at iii.

80. JUDICIAL BENCHBOOK, supra note 13, at 2.

81. HUdDLESTON \& MARLOWE, supra note 61, at 14-15.

82. See Bureau of Justice Assistance, U.S. DeP'T of Justice, OMB No. 1121-0329, Adult Drug Court Discretionary Grant Program Fy 2013 Competitive Grant ANNOUNCEMENT 4-5 (2012), available at https://www.bja.gov/Funding/13DrugCourtSol.pdf.

83. Id. at 5 ("Drug courts funded through this grant solicitation . . must operate the adult drug court based on BJA's and the National Association of Drug Court Professionals' publication: Defining Drug Courts: The Key Components.”).

The purpose of the Adult Drug Court Discretionary Grant Program . . . is to provide financial and technical assistance to states, state courts, local courts, units of local government, and Indian tribal governments to develop and implement drug courts that effectively integrate evidence-based substance abuse treatment, mandatory drug testing, sanctions, and incentives, and transitional services in a judicially supervised court setting with jurisdiction over substance-abusing offenders. Id. at 4 .

84. FEASIBILITY STUDY, supra note 17, at 2.

85. Mo. REV. STAT. § 478.001(1) (2012).
} 
court participants." 86 Today there are currently seventy-four drug courts operating in the state (over 120 problem-solving courts in all), ${ }^{87}$ and these courts are funded by a combination federal, state, and local sources. ${ }^{88}$ Every drug court in Missouri is presided over by a judge, who is appointed by the majority of the judges in the circuit (county). ${ }^{89}$ Each circuit has discretion to establish its own conditions for drug court referral. $^{90}$ That said, most drug courts in Missouri are pre-plea diversionary programs, meaning the offender's charges are dismissed upon successful completion of the program. ${ }^{91}$

In Arkansas, the legislature recognized " $[\mathrm{t}]$ here is a critical need for judicial intervention and support for effective treatment programs that reduce the incidence of drug use, drug addiction, and family separation due to parental substance abuse and drug-related crime." 92 In light of such a need, the legislature attempted to "enhance public safety by facilitating the creation, expansion, and coordination of drug court programs" across the state. ${ }^{93}$ Further, "the goals of the drug court program in [Arkansas] shall be consistent with the standards adopted by the United States Department of Justice and recommended by the National Association of Drug Court Professionals and shall include the [Ten Key Components]." ${ }^{94}$ Drug court practice in Arkansas is very similar to drug court practice in Missouri, ${ }^{95}$ and there are currently fiftyone adult and juvenile drug courts operating across the state. ${ }^{96}$ Likewise, Nebraska, ${ }^{97}$ Illinois, ${ }^{98}$ and Oklahoma ${ }^{99}$ (to list a few other states) have all instituted drug courts.

\footnotetext{
86. Id

87. NAT'L ASS'N OF DRUG COURT PROF'LS, supra note 20.

88. FEASIBILITY STUDY, supra note 17, at 29.

89. Mo. ReV. STAT. § 478.003 (2012).

90. Id. $\S 478.005(1)$.

91. FeAsibiLity Study, supra note 17, at 31 .

92. ARK. CODE ANN. § 16-98-302(a) (2013).

93. Id.

94. Id. § 16-98-302(b)(1)-(10).

95. See, e.g., id. § 16-98-302(c)(1)-(2), §16-98-303(d)(1)-(3).

96. NAT'L ASS'N OF DRUG COURT PROF'LS, supra note 20.

97. Neb. Rev. Stat. ANN. § 6-1204 (West 2013).

98. 730 Ill. Comp. Stat. 166/15 (West 2013).

99. OKLA. StAT. ANN. tit. 22, $\$ 471.1$ (West 2013).
} 


\section{ANALYSIS}

\section{A. Problems with an Overly Narrow Target Population}

The purpose of SB 123 is to address the significant problem of recidivism among drug-addicted offenders. ${ }^{100}$ The Kansas Supreme Court noted in Preston that the Kansas Sentencing Commission had analogized this particular problem to a "revolving door." 101 The use of this analogy by the commission is an acknowledgment of the fact that substance-dependent offenders in Kansas are continuously in and out of prison as a result of their addictions. Acknowledging this predicament in word, however, is not the same as acknowledging it in action. As described above, SB 123 is extremely limited in scope-primarily in three ways. First, only offenders convicted of possession of a controlled substance are eligible for the program. Second, within this alreadynarrow category of offenders, only first-time and second-time felony possession offenders are eligible. ${ }^{102}$ Lastly, the sentence for a third or subsequent felony possession conviction shall be imprisonment. ${ }^{103}$ Herein lies the problem with SB 123: the rhetoric behind the law is subverted by its own restrictions.

The effectiveness of SB 123 in breaking the recidivistic cycle of drug-addicted offenders is seriously undermined by limiting eligibility to only those offenders convicted of drug possession at the exclusion of all other criminal offenders. This limitation ignores the large population of other offenders whose criminal acts were driven by drug dependency. It is important to understand that drug-dependent offenders do not practice a restrained criminality. They commit other offenses besides mere possession; and, such offenses are likely spread across the criminal spectrum. ${ }^{104}$ After all, serious drug use and negative behavioral patterns

\footnotetext{
100. State v. Preston, 195 P.3d 240, 244 (Kan. 2008).

101. Id.

102. Kan. Stat. AnN. § 21-6805(f)(1) (West 2013); see also SB 123 Operations ManuaL, supra note 26 , at ch. 4-2.

103. KAN. STAT. ANN. § 21-6805(f)(1) (West 2013).

104. NAT'L CTR. ON ADDICTION \& SUBSTANCE ABUSE, supra note 1, at 2 (“Substance misuse and addiction are overwhelming factors in all types of crime, not just alcohol and drug law violations. Thirty-seven percent of federal, state and local prison and jail inmates in 2006 were serving time for committing a violent crime as their controlling offense; of these inmates, 77.5 percent were substance involved. Those serving time for property crimes comprise 19.2 percent of the inmate population; 83.4 percent were substance involved. Those whose controlling offense was a supervision violation, public order offense, immigration offense or weapon offense comprise 13.3 percent of the inmate population; 76.9 percent were substance involved."); see also DrugFacts:
} 
often go hand-in-hand. ${ }^{105}$ For example, to continue supporting his habit, an individual suffering from addiction may resort to theft, robbery, or burglary. While under the influence, such a person may drive while impaired or assault another individual. Simply put, people addicted to drugs do not engage in a limited brand of crime. Limiting drug treatment to only possession offenders, implicitly and incorrectly assumes that individuals who possess illegal drugs are the only offenders addicted to drugs. Recently, a number of Kansas judges were consulted to voice their opinion regarding SB $123 .{ }^{106}$ Discussing the fact that SB 123 is limited to only the offense of possession:

Almost half of the judges interviewed were . . . concerned about offenders who, in their views, should receive SB 123 because of the nature of their substance abuse problems but cannot due to the fact that their criminal history makes them ineligible for inclusion under SB 123. One judge stated that there are many cases where individuals commit more serious crimes where the offender is an addict and they are not eligible for $S B 123$ treatment because of the seriousness of the current charge, but those people are the ones who probably need the most help because they are committing serious crimes to feed their addiction. A few judges reported that there are a group of offenders that commit non-drug related crimes and

Treatment for Drug Abusers in the Criminal Justice System, DRUGABUSE.GOV (July 2006), http://www.drugabuse.gov/publications/drugfacts/treatment-drug-abusers-in-criminal-justice-system (noting that "the connection between drug abuse and crime is well known"); DrugFacts: Understanding Drug Abuse and Addiction, DRUGABUSE.GOV (Nov. 2012),

http://www.drugabuse.gov/publications/drugfacts/understanding-drug-abuse-addiction ("Brain imaging studies of drug addicted individuals show changes in areas of the brain that are critical to judgment, decision making, learning and memory, and behavior control. Together, these changes can drive an abuser to seek out and take drugs compulsively despite adverse, even devastating consequences - that is the nature of addiction." (emphasis added)). See generally Ruben D. Baler \& Nora D. Volkow, Drug Addiction: The Neurobiology of Disrupted Self-Control, 12 TRENDS MoleCUlaR MED. 559, 559 (2006) (noting that there is an "intimate relationship between the circuits disrupted by abused drugs and those that underlie self-control," and that a "fundamental motivational shift takes place whereby a drug is no longer taken to derive pleasure from it but to satiate intense craving and to relieve the distress of not having the drug").

105. Daniel H. Angres, The Temperament and Character Inventory in Addiction Treatment, $8 \mathrm{~J}$. LIFELONG LEARNING \& PSYCHIATRY 187, 188-89 (2010) ("A study published in the American Journal of Psychiatry revealed that $60 \%$ of subjects with substance use disorders had personality disorders.... There are a number of different views regarding personality and addiction. . . [S] ubstance abuse often occurs within the context of a deviant peer group and antisocial behaviors might be shaped and reinforced by social norms.... Patients with ... antisocial personality disorder and borderline personality disorder, have been suggested to have the highest prevalence of addiction ....").

106. Don Stemen \& Andres F. Rengifo, Alternative Sentencing Policies for Drug OFFENDERS: EVAluAting THE EFFECTIVENESS OF KANSAS SENATE BILl 123, FinAl REPORT, 14849 (2012), available at https://www.ncjrs.gov/pdffiles1/nij/grants/238012.pdf [hereinafter SB 123 EVALUATION]. 
who are in serious need of substance abuse treatment as well as those included under SB $123 .^{107}$

The goal of SB 123 to "address more effectively the revolving door of drug addicts in the state prisons" is further sterilized by limiting eligibility to only those first-time or second-time felony possession offenders. To stop the revolving door of recidivism, the criminal justice system must target persons actually caught up in its swirling vortex. SB 123's eligibility limitations keep the program from reaching the people truly caught up in the justice system, and they ignore the fact that these individuals (because of their addiction) are at much greater risk for having more than one or two felony possession convictions. In its study on the feasibility of drug courts in Kansas, the NCSC noted this problem:

Kansas would see a greater cost benefit if SB 123 programs ... were available to a broader range of offenders. By accepting only first and second time felony possession offenders for drug possession, the programs are not catching the individuals who are caught in the revolving door of substance abuse and criminal behavior.

It can hardly be said that a person facing a first or second felony possession offense is caught up in a cycle of criminal justice appearances. These are the people who, more likely than not, need probationary drug treatment the least. Even more problematic is the fact that when a person is convicted of possession for a third or subsequent time, the presumptive sentence is imprisonment, and the court "shall" sentence the offender to prison. ${ }^{109}$ SB 123 exacerbates the very problem it seeks to solve! Rather than pulling offenders out of the revolving door, SB 123 throws them back in.

Providing only a single opportunity at drug treatment further strangles the effectiveness of SB 123. This limitation fails to consider that addicted individuals are likely to relapse multiple times; ${ }^{110}$ and, it

\footnotetext{
107. Id. at $161-62$.

108. FEASIBILITY STUDY, supra note 17, at 9-10.

109. KAN. STAT. ANN. § 21-6805(f)(1) (West 2013)

110. Nat'l Inst. on Drug Abuse, Drugs, Brains, and Behavior: The Science of ADDICTION 26 (2010), available at http://www.drugabuse.gov/sites/default/files/sciofaddiction.pdf [hereinafter THE SCIENCE OF ADDICTION]; see also AM. PSYCHIATRIC Ass'N, supra note 70, at 189 ("The course of [s]ubstance [d]ependence is variable. Although relatively brief and self-limited episodes may occur ... the course is usually chronic, lasting years, with periods of exacerbation and partial or full remission. There may be periods of heavy intake and severe problems, periods of total abstinence, and times of nonproblematic use of the substance, sometimes lasting for months.... During the first 12 months after the onset of remission, the individual is particularly vulnerable to
} 
often takes multiple attempts at treatment for these individuals to get permanently clean. ${ }^{111}$ After all, drug addiction is considered a chronic disease characterized by compulsive drug seeking and use. ${ }^{112}$ Considering the chronic nature of drug addiction, "[R]elapsing to drug abuse is not only possible, but likely. ... Treatment of chronic diseases involves changing deeply imbedded behaviors ...."113 This is not to say that repeat offenders, previously unsuccessful in probationary drug treatment, should be given grace ad nauseam. However, providing only one opportunity at drug treatment ignores the reality of drug addiction and only undermines the goals of SB 123.

\section{Comparing SB 123's Eligibility and Admission Requirements to} Drug Court Practice

The eligibility restrictions and limitations of SB 123 are also contrary to drug court practice, which has been proven effective in reducing "recidivism and substance abuse among high-risk substance abusing offenders and increase[ing] their likelihood of successful rehabilitation ...." $" 114$ The first key component of drug court provides a broad mission statement: "The mission of drug courts is to stop the abuse of alcohol and other drugs and related criminal activity."115 The phrase "related criminal activity" necessarily implies any criminal activity related to drug abuse and addiction. This mission statement recognizes that the problem is not a particular brand of crime, but a particular brand of criminal. Importantly, drug courts are not limited to a certain type of offense; they are only limited to a certain type of offender - the offender that is addicted to drugs.

Drug court eligibility is not limited to only those offenders convicted of possession. ${ }^{116}$ Drug courts generally target non-violent misdemeanor or felony offenders where drugs were the underlying cause or motivator

\footnotetext{
having a relapse." (emphasis added)).

111. See JUdICIAL BENCHBOOK, supra note 13, at 68-70. (relating the clinical understanding that addiction recovery is a lengthy process, and "[i]f it took months or years to lay down drugrelated pathways, then it could be expected to take months or years to lay down newer pathways that can compete effectively against drug or alcohol abuse").

112. THE SCIENCE OF AdDICTION, supra note 110, at 5; AM. PSYCHIATRIC Ass'N, supra note 70 , at 189 .

113. THE SCIENCE OF ADDICTION, supra note 110, at 26.

114. BuREAU OF JUSTICE ASSISTANCE, supra note 82, at 4.

115. TEN KEY COMPONENTS, supra note 62, at 1.

116. FEASIBILITY STUDY, supra note 17, at 8 (see chart comparing SB 123 to drug courts).
} 
of the crime. ${ }^{117}$ The NCSC noted that, "less than one-third of prior convictions in all courts were drug-related; this indicates that [drug court] participants are involved in a wider range of criminal activity."118 The reasoning behind this broad inclusion of any drug-addicted offender, as explained above, is grounded in extensive research. The NCSC reported further that "[r]esearch shows definitively that drug courts are most effective for high-risk / high-needs offenders. Most high-risk / high-needs individuals have multiple convictions, are highly addictive and have failed at treatment before." 119

Because most dual high-risk and high-need individuals have previously failed drug treatment, many states that have institutionalized drug courts allow judges to determine whether an offender will get more than one chance at drug court treatment. In Missouri, the only conditions imposed upon eligibility of drug-addicted offenders are that the offenders be non-violent and that the referral to drug court be agreed upon by both parties. $^{120}$ Similarly, Arkansas denies drug court admission only to individuals previously convicted of sexual or violent offenses. ${ }^{121}$ Oklahoma requires that drug-addicted offenders have no violent offenses within the previous ten years, ${ }^{122}$ admit to having an addiction to drugs, ${ }^{123}$ volunteer for the program, ${ }^{124}$ get approval from the prosecuting attorney, and subsequently appear before a judge who determines admission into the drug court program. ${ }^{125}$ The point here is not to catalog drug court admission criteria, but rather to show how many states do not deny admission into drug court to those who have previously failed drug treatment. Kansas's one-shot rule denies courts the discretion to determine the best sentence for each offender.

The eligibility and admission provisions of SB 123 not only undermine the aspirations of the law, but are also contrary to effective drug court practice. In light of these problematic eligibility restrictions, SB 123's eligibility scheme should be replaced in the event drug courts

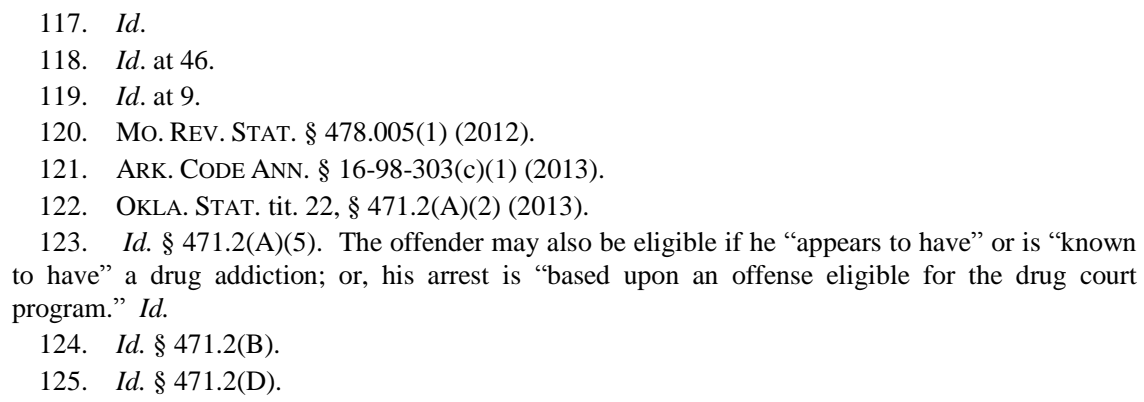


are institutionalized across the state. Even if SB 123 is used as a basis for institutionalized drug courts in Kansas, the law should be expanded to target a larger population. SB 123 drug treatment should focus not only on offenders heading towards the revolving door, but also on offenders already trapped therein.

\section{B. The Problem with Lacking Continuous Judicial Supervision}

SB 123 is lacking in another significant way: there is no continuous judicial involvement. The first key component of drug court states that "[d]rug courts integrate alcohol and other drug treatment services with justice system case processing." "126 In drug courts, "the treatment experience begins in the courtroom and continues through the participant's drug court involvement. In other words, drug court is a comprehensive therapeutic experience, only part of which takes place in a designated treatment setting. The treatment and criminal justice professionals are members of the therapeutic team." ${ }^{\text {"27 }}$ Drug courts require that each team member play an active role in a participant's progress. ${ }^{128}$ Studies have shown that when any one of these team members were regularly absent, participant results were $50 \%$ less favorable. ${ }^{129}$

Moreover, drug court offenders regularly appear and give progress reports to judges, prosecutors, defense attorneys, probation officers, treatment providers, and other criminal justice personnel. These regular, status hearings have been shown to be a critical aspect of drug court effectiveness. ${ }^{130}$ Importantly, such hearings are non-adversarial. ${ }^{131}$ To be sure, courts require that participants actually participate in treatment and sanctions are imposed for non-compliance. However, as part of the treatment program, courts also understand that addiction takes time to conquer-participants are going to have issues with compliance and

\footnotetext{
126. Ten Key Components, supra note 62, at 1.

127. Id. at 7 (emphasis added).

128. MARLOWE, supra note 15, at 4; see also TEN Key COMPONENTS, supra note 62, at 7.

129. MARLOWE, supra note 15, at 4.

130. Id

131. Ten Key Components, supra note 62, at 3 ("To facilitate an individual's progress in treatment, the prosecutor and defense counsel must shed their traditional adversarial courtroom relationship and work together as a team. Once a defendant is accepted into the drug court program, the team's focus is on the participant's recovery and law-abiding behavior-not on the merits of the pending case.").
} 
relapse. ${ }^{132}$ Thus, drug courts combine the "hammer" of the justice system with this therapeutic approach. This approach holds the participant appropriately accountable while, at the same time, providing needed treatment services.

Some aspects of SB 123 are similar to drug court, for example, stateprovided drug treatment, and the ability to impose sanctions. Outside of sanctions and the revocation process, SB 123 lacks judicial involvement in the treatment process. This is extremely significant because judicial involvement is the critical piece of drug court practice. Without continuous judicial supervision, the offender lacks a major external motivation to change. Even though the threat of judicial sanction is present, such sanctions sit outside the treatment process, are not immediately available, and are imposed by a judge not intimately involved with the offender's case.

\section{SB 123's Mandatory Admission and Revocation Requirements and the Denial of Jail-Time Credit}

As shown above, SB 123 requires that those offenders who meet the eligibility and admission criteria within K.S.A. section 21-6824 must be admitted into the program. ${ }^{133}$ Whether the offender desires probationary drug treatment is irrelevant. While in the program, offenders are subject to sanctions if they fail to abide by the terms of their probation or treatment. ${ }^{134}$ Offenders are discharged if they commit a new felony. ${ }^{135}$ Also, if an offender "fails to participate in or has a pattern of intentional conduct that demonstrates the defendant's refusal to comply with or participate in the treatment program ... the defendant shall be subject to . . . revocation pursuant to the provisions of K.S.A. $\$ 22-3716$."136 Moreover, as the Kansas Supreme Court has held, these are not the only two circumstances for which an offender may be discharged from the program. ${ }^{137}$ Importantly, offenders do not receive jail-time credit for time spent in treatment if they are terminated and their underlying sentence is imposed. ${ }^{138}$ The mandatory admission and revocation

\footnotetext{
132. See supra note 109-12 and accompanying text.

133. KAN. STAT. ANN. § 21-6824(c) (West 2013).

134. Id. \$ 22-3716(g).

135. Id. $\S 21-6824(\mathrm{f})(1)(\mathrm{A})$.

136. Id. § 21-6604(n)(2).

137. State v. Gumfory, 135 P.3d 1191, 1196 (Kan. 2006).

138. Id. § 21-6604(n)(1), amended by 2013 Kan. Sess. Laws Ch. 76, Sec. 1.
} 
requirements of SB 123, coupled with the law's denial of jail-time credit, are problematic for two reasons. These provisions increase the rate of offender recidivism and generate serious due process concerns.

\section{The Effect of SB 123's Mandatory Admission and Revocation Requirements on Recidivism}

SB 123 is counterproductive in that, while it is too narrow, it is also too broad. As mentioned above, the law is too narrow because SB 123 drug treatment is limited to those convicted of felony drug possession for the first or second time. Because admission into SB 123 is mandatory, the law is too broad at the same time. Today, unlike ten years ago, all "high risk" first- or second-time possession offenders are forced into SB 123 probationary drug treatment. ${ }^{139}$ Once in the program, offenders face a probation involving greater supervision, more demanding requirements, and more stringent revocation guidelines. The mandatory nature of SB 123 thus becomes problematic.

"Net-widening" is a phenomenon that occurs when a non-prison sentence such as probation actually increases, rather than decreases, prison sentences. ${ }^{140}$ Net-widening can occur anytime a jurisdiction places more offenders into probation programs with increased requirements and additional supervision. ${ }^{141}$ The more jurisdictions monitor and restrict probationers, the more likely it is that violations will be discovered. ${ }^{142}$ Because more violations are discovered, jurisdictions

139. Id. § 21-6824(c)

140. Michelle S. Phelps, The Paradox of Probation: Community Supervision in the Age of Mass Incarceration, 35 L. \& POL'Y 51, 52-53, 56 (2013).

141. See id. at 52 (noting that, despite the positive misconception that probation decreases prison sentences, research on probation has historically found that probation "expand[s] the 'net' of formal social control").

[R]esearchers [have] often found that expansions in probation increase[] overall punishment by drawing in more low-level cases (who might otherwise have been sentenced with community service hours, fines, or other ... less invasive punishments) and [make] these individuals more likely to be incarcerated in the future due to increased Id. restrictions and monitoring.

142. Michael Tonry \& Mary Lynch, Intermediate Sanctions, 20 CRIME \& JUST. 99, 101 (1996) ("The goals of diverting offenders from prison and providing tough, rigorously enforced sanctions in the community have proven largely incompatible. A major problem, and it has repeatedly been shown to characterize intensive supervision programs, is that close surveillance of offenders reveals higher levels of technical violations than are discovered in less intensive sanctions." (emphasis added)). 
revoke probation and impose underlying prison sentences more often. ${ }^{143}$

Considering the general qualities of the typical possession offender in light of the increased probationary standards of SB 123, it becomes clear that net-widening will likely occur as the rate of violations and revocations increase. ${ }^{144}$ The reason is simple. Drug possession offenders are more likely to have problems with substance abuse and addiction than other offenders. Obviously, because such offenders are at a greater risk of using illicit drugs, they are at high risk of violating the terms of their probation. The possession offenders placed in SB 123, therefore, are at a greater risk of being revoked, especially because revocation is mandatory for certain offenses.

This has already proven to be the case for SB 123. In 2012, an extensive study by Don Stemen and Andres Rengifo of the National Institute of Justice examined the effectiveness of SB $123 .{ }^{145}$ The study acknowledged the net-widening effect of SB 123's mandatory admission requirements and provided this damning conclusion:

SB 123 [has] a limited impact on recidivism. SB 123 increase[s] the likelihood of recidivism compared to court services and ha[s] no significant impact on recidivism compared to community corrections or prison. The impact relative to court services may not be surprising; most failures on probation are the result of revocations and SB 123 increase[s] the level of surveillance and control drug possessors were subjected to in the community [thus] increasing the likelihood of revocation. ${ }^{146}$

Therefore, rather than decrease the rates of recidivism and the subsequent imposition of prison sentences, SB 123 actually increases the likelihood that a possession offender will reoffend and be sent to prison.

\section{Due Process Concerns Regarding the Denial of a Jail-Time Credit}

Apart from the concern regarding SB 123 probationer success rates, mandatory admission into SB 123 probation is disconcerting for another

143. Id. (noting that there is no reason to believe offenders in intensive supervision programs commit more violations; the reason for higher rates of violations and subsequent revocations is that offenders are more closely monitored, which increases the chance that violations will be discovered).

144. See SB 123 Evaluation, supra note 106, at 205 (“[M]ore drug possessors are now subject to stricter conditions and greater surveillance than prior to implementation of SB 123; a situation that may be leading to higher rates of revocation.").

145. Id. at 4-5.

146. Id. at 206 . 
reason. Offenders placed in SB 123 will not be given a jail-time credit in the event their probation is revoked. As mentioned above, the right to jail-time credit is statutory for "standard" probationers in Kansas. ${ }^{147}$ In the event an offender's probation is revoked, the court must reduce the offender's prison sentence by the amount of time spent in confinement during his or her probation. ${ }^{148}$ SB 123 probationers, however, do not receive the same treatment. In creating this separate class of probationers, the Kansas Legislature decided that time spent in an SB 123 program will not count towards the underlying prison sentence. ${ }^{149}$ This distinction between standard probationers and SB 123 probationers creates constitutional concerns involving offenders' due process rights.

The Due Process Clause of the Fourteen Amendment ${ }^{150}$ requires that each state afford procedural protections before the government may deprive an individual of a "life," "liberty," or "property" interest. ${ }^{151}$ The basic due process question is: when the government deprives an individual of a life, liberty, or property interest, what process is due? ${ }^{152}$ This question allows for a flexible response-it requires procedural protections as each particular situation demands. ${ }^{153}$ The Kansas Supreme Court put it this way: "The fundamental requirement of due process is the opportunity to be heard at a meaningful time and in a meaningful manner. ... A due process violation exists only when a claimant is able to establish that he or she was denied a specific procedural protection to which he or she was entitled."154

An individual charged with a crime has an obvious liberty interest at stake when facing potential incarceration and is entitled to due process protections. Such protections include notice and an opportunity to be

\footnotetext{
147. Kan. Stat. ANN. § 21-6615 (West 2013).

148. Id

149. Id. § 21-6604(n)(1).

150. U.S. Const. amend. XIV, $\S 1$ ("“N]or shall any State deprive any person of life, liberty or property, without due process of law ....").

151. Id.; Mathews v. Eldridge, 424 U.S. 319, 348 (1976) ("The essence of due process is the requirement that 'a person in jeopardy of serious loss (be given) notice of the case against him and [the] opportunity to meet it." (quoting Joint Anti-Fascist Refugee Comm. v. McGrath, 341 U.S. 123, 171-72 (1951) (Frankfurter, J., concurring))).

152. Morrissey v. Brewer, 408 U.S. 471, 481 (1972) ("Once it is determined that due process applies, the question remains what process is due.").

153. Id.; see also Mathews, 424 U.S. at 334 (““[D]ue process, unlike some legal rules, is not a technical conception with a fixed content unrelated to time, place and circumstances." (quoting Cafeteria Workers v. McElroy, 367 U.S. 886, 895 (1961))).

154. In re J.D.C., 159 P.3d 974, 982 (Kan. 2007). See also Winston v. State Dept. of Soc. Rehab. Servs., 49 P.3d 1274, 1283-84 (Kan. 2002) (providing the standard for evaluating procedural due process claims).
} 
heard at a fair and adequate trial. ${ }^{155}$ Due process protections, however, do not end at trial. Criminal defendants are also entitled to due process at sentencing. According to the Supreme Court, "it is now clear that the sentencing process, as well as the trial itself, must satisfy the requirements of the Due Process Clause."156 Further, at sentencing, "free-standing due process constitutes the almost exclusive source of constitutionally mandated procedural rights." ${ }^{157}$ According to one scholar's summary:

Due process governs the range of conduct and type of information that may be considered by the sentencing judge, the need for notifying the defendant of the information that the judge will consider in making the sentencing decision, the need to ensure that information relied upon is accurate, and the need to provide the defendant with an opportunity to be heard and to offer his own evidence. ${ }^{158}$

Indeed, due process today:

$[R]$ ecognizes that adversary procedural rights are needed at [sentencing], just as at the criminal trial, because the length and terms of the sentence implicate the defendant's liberty interest no less than conviction itself. The judge's determination of the length of the sentence, or her choice between a prison term, home confinement, or probation, may affect the defendant's interests as keenly as the fact of conviction.

Because of judicial discretion in sentencing and the liberty interest at stake, criminal defendants have the right to be heard in a meaningful way

155. State v. Wilkinson, 9 P.3d 1, 5 (Kan. 2000); see also Fuentes v. Shevin, 407 U.S. 67, 80 (1972) (noting that "[f]or more than a century the central meaning of procedural due process has been clear: '[p]arties whose rights are to be affected are entitled to be heard; and in order that they may enjoy that right they must first be notified"' (citing Baldwin v. Hale, 68 U.S. 223, 233 (1863))); McGrath, 341 U.S. at 171-72 (Frankfurter, J., concurring) ("No better instrument has been devised for arriving at truth than to give a person in jeopardy of serious loss notice of the case against him and opportunity to meet it."); Niki Kuckes, Civil Due Process, Criminal Due Process, 25 YAle L. \& POL'Y REV. 1, 18-19 (2006) (discussing the "impressive degree" of due process protections afforded to criminal defendants at trial and the origins of those protections).

156. Gardner v. Florida, 430 U.S. 349, 358 (1977). "Even though the defendant has no substantive right to a particular sentence within the range authorized by statute, the sentencing is a critical stage of the criminal proceeding. ... The defendant has a legitimate interest in the character of the procedure which leads to the imposition of sentence even if he may have no right to object to a particular result of the sentencing process." Id.

157. Jerold H. Israel, Free-Standing Due Process and Criminal Procedure: The Supreme Court's Search for Interpretive Guidelines, 45 ST. LoUIS U. L.J. 303, 394 (2001).

158. Id. at 393.

159. Kuckes, supra note 155 , at 19. 
at sentencing, and are therefore provided due process rights at the sentencing stage.

The mandatory admission requirement of SB 123 effectively eliminates an offender's opportunity to be heard at sentencing by eliminating the judge's discretion to sentence. As noted above, the statute requires courts to sentence first- and second-time felony possession offenders to drug treatment. ${ }^{160}$ When the judge has no choice but to sentence a possession offender to SB 123 treatment, the offender has no voice in the matter. Whether an offender is adamantly opposed to drug treatment, desires standard probation, or wishes to serve the underlying prison sentence is of no consequence. SB 123 probationary drug treatment is mandatory. The possession-offender eligible for SB 123 , therefore, has no opportunity to be heard at sentencing.

Does the denial of an offender's right to be heard at sentencing through the imposition of a mandatory sentence constitute a denial of due process? The answer at first appears to be "no." Due process attacks against mandatory sentences have been made numerous times in the past, and such attacks have often focused on mandatory impositions of minimum prison sentences following a repeated or aggravated offense. ${ }^{161}$ Offenders attack mandatory prison sentences with the argument that they denied the judge discretion to suspend or reduce the sentence, and (as the argument goes) thus deprived the offender due process at sentencing. ${ }^{162}$ This argument has generally lost as courts have consistently held that mandatory sentences are constitutionally valid and do not violate defendants' due process rights. ${ }^{163}$ The driving justification

160. KAN. StAT. ANN. § 21-6824(c)(1) (West 2013).

161. See, e.g., United States v. Chandler, 395 F. App’x 908 (3d Cir. 2010) (mandatory minimum prison sentence imposed for offenses involving crack cocaine); United States. v. Nolan, 342 F. App'x 368, 371 (10th Cir. 2009) (mandatory minimum sentence of fifteen years imprisonment for any individual who is statutorily classified as an "armed career criminal"); United States v. Santos, 64 F.3d 41 (2d Cir. 1995) (mandatory thirty year minimum prison sentence for using a silenced firearm during drug trafficking crime), vacated, 516 U.S. 1156 (1996); State v. Spain, 953 P.2d 1004 (Kan. 1998) (mandatory term of forty years imprisonment for premeditated first-degree murder); State v. DeCourcy, 580 P.2d 86 (Kan. 1978) (mandatory minimum prison sentence for carrying firearm during commission of certain crimes).

162. See, e.g., State v. Freeman, 574 P.2d 950 (Kan. 1978) (defendant argued that mandatory minimum sentence of 5 years imprisonment denied judge discretion to grant a lesser sentence, thus constituting a denial of defendant's due process rights).

163. See, e.g., State v. Boldridge, 57 P.3d 8, 20 (Kan. 2002) (holding that a "hard 50" sentence does not violate a defendant's due process rights); Decourcy, 580 P.2d at 88 (mandatory minimum prison sentence for carrying a firearm during the commission of a certain offense does not violate defendant's due process rights); see also 24 C.J.S. Criminal Law $§ 2005$ (2013) ("A statute providing a mandatory sentence... is generally constitutional...."). See generally Annotation, 
behind such approval arises out of the legislature's power to define punishment for specific crimes. ${ }^{164}$ After all:

The power of the legislature to fix the punishment for crime is practically unlimited; it may take property, it may take liberty, it may take life, in punishment for an infraction of the law, so long as it does not in so doing infringe or violate any of the guaranties secured to all citizens by the Constitution. ${ }^{16}$

Indeed, the Kansas Supreme Court has noted that "fixing and prescribing of penalties for violating the criminal statutes of this state is a legislative function." 166

It is important to note, however, that mandatory sentences today are not fixed, one-size-fits-all sentences in which a judge has absolutely no discretion - that is, they are not truly mandatory. Rather, "mandatory sentence" generally refers to a sentence that falls within a legislatively provided minimum and maximum sentencing range to which the judge must abide. ${ }^{167}$ Such sentencing provisions merely reduce the amount of discretion a judge may utilize at sentencing. ${ }^{168}$ Though truly mandatory fixed sentences were a part of our nation's early history, "[m]odern mandatory sentence enhancement legislation differs from the fixed sentences imposed [historically]. Most of the current laws do not set the penalties for criminal offenses themselves, but instead require substantially increased punishment when a specified aggravating circumstance exists in connection with the commission of a crime." 169

Constitutionality of Statute Which Makes Specified Punishment or Penalty Mandatory and Permits No Exercise of Discretion on Part of Court or Jury, 83 A.L.R. 1362 (2013) [hereinafter Constitutionality of Statute].

164. DeCourcy, 580 P.2d at 88.

165. Constitutionality of Statute, supra note 163.

166. DeCourcy, 580 P.2d at 88.

167. Gary T. Lowenthal, Mandatory Sentencing Laws: Undermining the Effectiveness of Determinant Sentencing Reform, 81 CALIF. L. REv. 61, 69 (1993).

168. In Kansas there are two sentencing guideline "grids" that judges use during sentencing. One grid covers nondrug crimes (K.S.A. § 21-6804) while the other grid covers drug crimes (K.S.A. $\S 21-6805)$. Though there are differences, both grids function the same. To use the nondrug grid as an example: "The sentencing guidelines grid for nondrug crimes as provided in this section defines presumptive punishments for felony convictions, subject to the sentencing court's discretion to enter a departure sentence." KAN. STAT. ANN. § 21-6804(d) (West 2013) (emphasis added). Furthermore, "The sentencing court has discretion to sentence at any place within the sentencing range. In the usual case it is recommended that the sentencing judge select the center of the range and reserve the upper and lower limits for aggravating and mitigating factors insufficient to warrant a departure." Id. § 21-6804(e)(1) (emphasis added).

169. Lowenthal, supra note 167 , at 69 .

A wide variety of circumstances trigger enhanced penalties under the statutes. Most 
Though mandatory admission to SB 123 drug treatment does not appear constitutionally problematic at first, SB 123 generates due process concerns distinguishable from those commonly raised against mandatory prison sentences. Unlike most "mandatory" sentences, the imposition of SB 123 probation is truly mandatory for eligible offenders. With most mandatory prison sentences, the sentencing judge utilizes discretion between the mandatory minimum and maximum possible sentences. Even though discretion is limited, it is not completely eliminated. SB 123 , on the other hand, imposes a truly fixed sentence. According to the statute, once a first or second felony possession has been deemed eligible, the judge has no discretion.

The biggest difference between the mandatory prison sentences mentioned above and SB 123 is that SB 123 statutorily requires probationary drug treatment. This becomes constitutionally significant because of several factors. First, there is a greater likelihood that possession offenders placed in SB 123 drug treatment will be drugdependent offenders. Second, offenders face increased supervision while in SB 123 drug treatment. Third, SB 123 probationers face potential sanctions that deprive them of liberty; ${ }^{170}$ and, any sanction involving confinement will not count as a jail-time credit against the underlying sentence for offenders removed from SB 123 probation. ${ }^{171}$ When one considers these factors, especially the nature of the SB 123 probationers themselves, denying offenders a voice at sentencing becomes problematic. Such a denial is problematic because offenders face a deprivation of liberty that goes beyond fair punishment.

As mentioned above, addicted individuals will likely relapse multiple times, and, consequently, repeatedly violate their probation. ${ }^{172}$ As a consequence of these violations, a drug-addicted offender forced into SB 123 could be sanctioned with house arrest, long-term inpatient drug treatment, and even 60 days in the county jail for failing to stay clean,

\footnotetext{
jurisdictions have adopted provisions requiring substantially longer prison sentences when a person possesses or uses a dangerous weapon during the commission of an offense. Enhanced sentences for repeat felony offenders are also common. Other common targets of enhancement legislation are persons who possess or distribute prohibited drugs exceeding a specified weight or amount, those who commit crimes against vulnerable victims such as children or elderly persons, and those who commit Id. at 70 . crimes while released from custody for other offenses.

170. KAN. Stat. ANN. § 22-3716(g) (West 2013).

171. Id. $\S 21-6604(\mathrm{n})(1)$.

172. See supra note 141 and accompanying text; THE SCIENCE OF ADDICTION, supra note 110, at 26 .
} 
submit a drug test, or adequately participate in treatment. ${ }^{173}$ If, at any time following a violation, an offender "fails to participate in or has a pattern of intentional conduct that demonstrates the [offender's] refusal to comply with or participate in the treatment program," then the offender could be removed from SB 123 and their underlying sentence imposed without credit for time already spent in confinement. ${ }^{174}$ Drugaddicted offenders are also at a much greater risk for picking up additional felonies. ${ }^{175}$ Likewise, if an individual is addicted to drugs, there is a greater likelihood that they will be caught possessing drugs, and in this instance, revocation is mandatory. ${ }^{176}$

In a remarkably detailed section regarding addiction and treatment, the Drug Court Judicial Benchbook (developed by the National Drug Court Institute) noted this low likelihood of success for drug offenders sentenced to drug treatment as a condition of their probation:

Unfortunately, drug offenders are notorious for failing to comply with their conditions to attend substance abuse treatment. Unless they are intensively supervised by the court, approximately twenty-five percent of drug offenders who have been ordered to attend substance abuse treatment will fail to enroll in treatment; and, among those who do arrive for treatment, approximately one-half will drop out of treatment prematurely.

Such concerns about the low chance of success in SB 123 drug treatment should be evident to all at the sentencing stage - especially the offender. As a number of Kansas courtroom actors have reported, "[A]lmost everyone who has participated [in SB 123] has been back in

173. Kan. STAT. AnN. § 22-3716(g) (West 2013).

174. Id. § 21-6604(n)(1)-(2) (2013), amended by 2013 Kan. Sess. Laws Ch. 76, Sec. 1.

175. The National Council on Alcoholism and Drug Dependence notes on its website that " $[t]$ he use of illegal drugs is often associated with murder, rape, robbery, aggravated assault, burglary, larceny / theft, serious motor vehicle offenses with dangerous consequences, arson and hate crimes. Without question, drug use and criminality are closely linked." Drugs and Crime, NCADD, http://www.ncadd.org/index.php/learn-about-drugs/drugs-and-crime (last visited Apr. 11, 2014); see also THE SCIENCE OF ADDICTION, supra note 110, at 7 ("The initial decision to take drugs is mostly voluntary. However, when drug abuse takes over, a person's ability to exert self control can become seriously impaired. Brain imaging studies from drug-addicted individuals show physical changes in areas of the brain that are critical to judgment, decision making . . . and behavior control. Scientist believe that these changes alter the way the brain works, and may help explain the compulsive and destructive behaviors of addiction." (emphasis added)).

176. See SB 123 Evaluation, supra note 106, at 15 (recommending that lawmakers revise SB 123 's revocation practices to reflect the likelihood that participants will relapse).

177. JUDICIAL BENCHBOOK, supra note 13, at 65 . 
court for [drugs] . . ."178

SB 123's sanctioning provisions, the statute's suspension of jail-time credit, and the characteristics of offenders placed into the SB 123 program create this overarching problem: SB 123 probationers face a substantial risk of being overly punished, with a substantial possibility that offenders will serve more time in confinement than is warranted by the underlying prison sentence for drug possession. ${ }^{179}$ When an offender could very likely face more time in confinement than the underlying prison sentence, then denying that offender a chance to be heard at sentencing is of serious concern. By mandating that an eligible first-time or second-time felony possession offender be sentenced to SB 123 probation, regardless of his or her inappropriateness for treatment, the legislature effectively sets the offender up for a protracted course of sanction and eventual revocation. This results in an unfair amount of punishment. This is a denial of due process.

To be sure, the imposition of standard probation may rightfully be considered a legislative "grace" given to the offender. ${ }^{180}$ Kansas Courts have repeatedly stated that "probation from service of a prison sentence is an act of grace by the sentencing judge and . . . is granted as a privilege, not as a matter of right." 181 However, when another "type" of probation, involving greater requirements and an increased amount of supervision, is forced on a group of individuals facing a great risk of failure, it can hardly be considered grace any longer. It is not enough to say that, since the legislature decreed it, it is therefore decided. The procedural due process protections of the Fourteenth Amendment impose constraints on the government when potentially depriving individuals of liberty. ${ }^{182}$ A major liberty interest is implicated when an offender could serve more time in confinement than the punishment presumes. Though the legislature has provided sentencing guidelines for criminal acts ${ }^{183}$ even harsh mandatory minimum prison sentences for certain egregious

178. SB 123 Evaluation, supra note 106, at 150.

179. A felony possession conviction is a level 5 felony drug offense. KAN. STAT. ANN. § 215706(c)(1)-(2) (West 2013). The underlying prison sentence for a felony possession offender with no prior felonies ranges from ten to fourteen months. Id. $\$ 21-6805$ (a). For those felony possession offenders with one or more prior non-person felonies, the sentencing range is fourteen to twenty-two months. Id.

180. See State v. DeCourcy, 580 P.2d 86, 88 (Kan. 1978).

181. State v. George, No. 108,374, 2013 WL 1729268, at*1 (Kan. Ct. App. Aug. 29, 2013) (emphasis added) (citing State v. Gary, 144 P.3d 634 (Kan. 2006)).

182. Mathews v. Eldridge, 424 U.S. 319, 332 (1976).

183. See supra note 168 . 
offenses ${ }^{184}$ - it has not long been in the business of completely removing a judge's discretion at sentencing, and in turn the offender's voice, by mandating probationary drug treatment. ${ }^{185}$ Aside from the fact that the mandatory imposition of probationary drug treatment is bad public policy, in light of the above concerns, it also constitutes a denial of due process.

\section{Standard Probationers v. SB 123 Probationers: Questions Involving Equal Protection.}

The distinction between standard probationers and SB 123 probationers inevitably brings up the question of equal protection. The Equal Protection Clause of the United States Constitution states: "No state shall deny to any person within its jurisdiction the equal protection of its laws." 186 The guiding principle of equal protection is that similarly situated individuals should be treated alike. ${ }^{187}$ Both the United States and Kansas Supreme Courts employ one of three tests to determine whether a legal classification violates equal protection: strict scrutiny, intermediate scrutiny, or rational basis review. ${ }^{188}$ Which test is used depends on the type of the classification and the rights that are effected by that classification. ${ }^{189}$

Generally, a law is subject to rational basis review unless the

184. See, e.g., KAN. STAT. ANN. § 21-6626 (West 2013) (sentencing "aggravated habitual sex offenders" to life imprisonment without the possibility of parole); id. § 21-6627 (sentencing those convicted of certain aggravated sex crimes to life imprisonment with a mandatory minimum term of twenty-five years); id. $\S 21-6620$ (a) (sentencing those convicted of capital murder who do not receive death to life imprisonment without the possibility of parole).

185. See State v. Gallegos, 190 P.3d 226, 234 (Kan. 2008) (finding that Kansas courts have discretion to impose any sentence within the presumptive sentencing range); State v. Richardson, 901 P.2d 1, 7 (Kan. 1995) (recognizing that the sentencing guidelines are "designed to regulate judicial discretion in sentencing but not eliminate it"); State v. Currie, 308 P.3d 1289, 1293 (Kan. Ct. App. 2013) (finding that presumptive sentences themselves are "subject to the court's discretion to enter a departure sentence"); see also State v. Freeman, 574 P.2d 950, 958 (1978) (noting that, although the judge was not statutorily authorized to grant probation or parole, the statute did not "have the effect of taking away all judicial discretion in fixing the sentence to be imposed," and "[i]t cannot be said that the sentencing court had no discretion in imposing [the] sentence").

186. U.S. ConST. amend. XIV, § 1. State v. Limon, 122 P.3d 22, 28 (Kan. 2005) (citing Farley v. Engelken, 740 P.2d 1058 (Kan. 1987)) ("Sections 1 and 2 of the Kansas Constitution Bill of Rights 'are given much the same effect as the clauses of the Fourteenth Amendment relating to ... equal protection of the law."').

187. Limon, 122 P.3d at 27 (citing City of Cleburne v. Cleburne Living Ctr., 473 U.S. 432, 440 (1985)).

188. Id. at 28 .

189. Id. (citing Romer v. Evans, 517 U.S. 620, 632 (1996)). 
legislative classification targets a suspect class or burdens a fundamental right. ${ }^{190}$ Mental illness or mental disability are not considered a suspect class, and will only be subject to rational basis review. ${ }^{191}$ Moreover, the rational basis test is two-fold: (1) the classification within the law must implicate a legitimate goal, and (2) the means chosen by the legislature to effectuate that goal must be rationally related. ${ }^{192}$ Rational basis review is a deferential standard, and courts will rarely strike down a classification under this test. ${ }^{193}$ So deferential is rational basis review that courts will uphold a law, even in the absence of legislative justification, if they themselves could conjure any rational basis for the classification. ${ }^{194}$

With this understanding of the basic tenets of equal protection, SB 123's denial of jail-time credit becomes immediately concerning. After all, is it not the case that offenders placed into SB 123 probation are being denied a right that is statutorily granted to all probationers? Does SB 123's denial of a statutorily granted jail-time credit not, therefore, constitute a violation of equal protection? The answer is "no." To start, drug addiction, as a recognized mental disorder by the American Psychiatric Association, ${ }^{195}$ is not a suspect classification-any classification, therefore, regarding drug addicts will be subject only to rational basis review. ${ }^{196}$

Further, a court could conjure rational reasons for why the Kansas Legislature decided to treat offenders forced into SB 123 drug treatment differently by denying them a jail-time credit. For example, the

190. Id. (citing Romer, 517 U.S. at 631).

191. Cleburne Living Ctr., 473 U.S. 432.

192. State v. Preston, 195 P.3d 240, 245 (Kan. 2008) (citing Mudd v. Neosho Mem. Reg. Med. Ctr., 62 P.3d 236 (Kan. Ct. App. 2003)).

193. See Hodel v. Indiana, 452 U.S. 314, 331-32 (1981) (recognizing that when classification is not suspect and does not "impinge on a fundamental right" it "carries with it a presumption of rationality that can only be overcome by a clear showing of arbitrariness and irrationality").

194. See Ry. Exp. Agency v. New York, 336 U.S. 106, 111-17 (1949) (Jackson, J., concurring). See also Heller v. Doe by Doe, 509 U.S. 312, 320-21 (1993) (providing a detailed examination of judicial deference regarding rational basis classifications and noting that every conceivable justification must be negated for an attack to prevail under this standard). "A State ... has no obligation to produce evidence to sustain the rationality of a statutory classification. "A legislative choice is not subject to courtroom factfinding and may be based on rational speculation unsupported by evidence or empirical data." Id. at 320 (quoting FCC v. Beach Commc'n, Inc., 508 U.S. 307, 315 (1993)).

195. See generally AM. PSYCHIATRIC ASS'N, supra note 70, at 189, 175-272 (providing descriptions and diagnostic criteria for various substance-related disorders).

196. Heller, 509 U.S. at 321 (citing Cleburne Living Ctr., 473 U.S. 432; Schweiker v. Wilson, 450 U.S. 221 (1981)) (recognizing that the Court has applied rational basis review to classifications involving the mentally disabled and mentally ill). 
legislature may have viewed such coercive treatment as a way to forcefully counter addiction. They may have considered the denial of jail-time credit as a means to coerce offender compliance with probationary drug treatment. Thus, the legislature could have had a rational basis for treating SB 123 probationers differently from ordinary probationers. When subject to such light scrutiny, there is no equal protection violation.

There is a more basic reason, though, for why an equal protection argument against SB 123 is bound to fail on legal grounds. In response to an SB 123 probationer's attack against on the law's denial of a jailtime credit, the Kansas Supreme Court noted in Preston that:

While a persuasive argument may be made for the legitimate goals supporting the unequal treatment of probationers ordered to inpatient treatment, we perceive a more basic impediment to [the SB 123 probationer's] equal protection claim. [Her] arguments rely on her classification of persons who are similarly situated as being all probationers. 'It is well settled that when circumstances differ, drawing distinctions . . . does not violate the Equal Protection Clause.' Accordingly, [the SB 123 probationer here] is similarly situated with all other S.B. 123 probationers; members of that class are not treated unequally ....

SB 123 probationers, according to the court, thus comprise a separate class of probationers. Since they comprise a separate class, there is no need to analyze whether the denial of a jail-time credit is in violation of equal protection, so long as all SB 123 probationers are denied such a credit.

Preston's holding, though resting on a relatively solid legal foundation, is nonetheless artificial when you consider that SB 123 probationers and standard probationers are not significantly different. By limiting admission to only those convicted of possession, SB 123 carries the incorrect assumption that these are the only offenders with drug problems. If this assumption were true, then there would indeed be a significant difference in circumstances between the two types of probationers. This assumption, however, is not true. ${ }^{198}$ As described

197. Preston, 195 P.3d at 245 (emphasis added) (quoting State v. Gaudina, 160 P.3d 854, (Kan. 2007)).

198. Illustrating the fact that SB 123 probationers do not characteristically differ from other offenders, many criminal justice professionals in Kansas have complained that many SB 123 probationers do not need treatment, while many other offenders do. SB 123 Evaluation, supra note 106 , at $158-65$. 
above, drug addiction leads to all types of crimes. ${ }^{199}$ Offenders of all types suffer from addiction, and are likewise in need of serious substance abuse treatment. ${ }^{200}$ To say that possession offenders placed in SB 123 probation are categorically different from other probationers is therefore inaccurate.

Further, assuming that both sets of probationers comprise a single class, it is important to consider the rationality of mandating SB 123 probation and denying a jail-time credit to those who fail the program. Just because the legislature's classifications pass constitutional muster does not mean that they achieve the legislature's goals. First, if the goal of SB 123 is to "provide community punishment and the opportunity for treatment to nonviolent offenders with drug abuse problems in order to more effectively address the revolving door of drug addicts through the state prison," 201 then, aside from limiting admission to only possession offenders, mandating drug treatment undercuts the goal of SB 123. Mandatory admission may actually serve as a hindrance by increasing rates of recidivism and subsequent revocation. ${ }^{202}$ Mandatory admission requirements "dismiss[] the significance of the individual's readiness [to] engage[] with treatment." 203 Moreover, "[a]s criminal justice stakeholders noted and offenders confirmed, the ultimate success of treatment depends on the individual ... SB 123 does not provide a clear mechanism for translating compulsory compliance with treatment through supervision and sanctions into internalized motivation."204 The denial of a jail-time credit - assuming this provision was intended to act as the "stick" to ensure offender compliance-presupposes a rational mind that will appropriately weigh the pros and cons of continued drug use in light of criminal punishment. The problem when dealing with

\footnotetext{
199. See supra notes 101-2.

200. See SB 123 Evaluation, supra note 106, at 160-62 (explaining that prosecutors, defense attorneys, and judges have all voiced frustration with SB 123's narrow eligibility requirements and the fact that such narrowness eliminates a great number of other offenders who need treatment). "[P]rosecutors [interviewed have] commented that '[SB 123] excludes people who need substance abuse treatment ... [and] the program lacks the subjective analysis of who will benefit from treatment...' One judge stated that 'there are many cases where [addicted] individuals commit more serious crimes ... [but] are not eligible for SB 123 treatment because of the seriousness of the current charge, but those people are the ones who probably need the most help because they are committing serious crimes to feed their addiction [sic]." Id.

201. Preston, 195 P.3d at 244 (quoting Feb. 12, 2003 memorandum from Kansas Sentencing Commission to the Senate Judiciary Committee).

202. SB 123 Evaluation, supra note 106, at 128-30.

203. Id. at 206.

204. Id
} 
those addicted to drugs, however, is that rational thought is severely compromised. ${ }^{205}$ To assume that drug-addicted offenders placed into SB 123 probation will refrain from drugs because they will not receive jailtime credit after revocation ignores the power of addiction. It cannot be said that mandatory admission and the denial of a jail-time credit furthers the underlying goals and objectives of SB 123.

\section{CONCLUSION}

Drug-addicted offenders pose a unique challenge to the criminal justice system - a challenge that requires an approach that is both bold and smart. Traditional sanctions are incapable of surmounting the problem of illicit drug abuse and addiction. In recent years, courts across the country have developed innovative and educated methods to better deal with this intractable problem. Through these efforts, drug courts have emerged as a proven way to check drug use and permanently remove drug-addicted individuals from the "revolving door" of criminal justice appearances.

Though SB 123 is a good-intentioned law that takes steps in the right direction, it has major deficiencies that severely undermine its goals and objectives. Apart from the law's serious constitutional concerns, it is simply bad public policy. SB 123 lacks the key ingredients responsible for drug court success-primarily, continuous judicial supervision. SB 123 is inflexibly limited to only a narrow class of drug offenders, which incorrectly assumes that only those caught in possession of drugs are in need of treatment. More importantly, SB 123 has stringent admission and termination requirements that ignore the nature of drug addictionexacerbating the very problem the program seeks to address. It is a waste of money and much needed resources to continue to sink money into such a program. Rather than continue with a half-hearted program, SB 123 should be replaced through the institutionalization of drug courts in Kansas. Having already proven their effectiveness, drug courts provide a better way.

205. See supra note 104 and accompanying text. 